The Canadian Journal of Higher Education, Vol. XXIII-1, 1993

La revue canadienne d'enseignement supérieur, Vol. XXIII-1, 1993

\title{
Gender, Education and Socioeconomic Status: Economic Theories, Credentialism and Beyond
}

\section{JEAN MCKENZIE LEIPER ${ }^{*}$}

\begin{abstract}
Human capital theory, market signalling theory and credentialism are explored as ways of explaining the relationship between formal education and socioeconomic status. For both men and women, years of schooling and diplomas or degrees help to ensure access to high-skill jobs which carry high socioeconomic status. The market signalling approach is relevant for men because skills are positively associated with socioeconomic status: employers value diplomas and degrees if they indicate that employees bring high skill levels to the labour market. The market signalling approach is not confirmed for women in this study. Some economists suggest that human capital theory is limited because it assumes women make voluntary choices to limit their education and job experience in favour of family responsibilities. Credentialism, by discounting the importance of skills acquired in school, ignores the issue of gender-based power differences that are related to skills. New theories are needed to address the issues of work and family commitments for both women and men.
\end{abstract}

* Department of Sociology and Anthropology, University of Guelph. The author would like to thank Tina Chui, Dana Harrison, Neil MacKinnon, and threc anonymous referees for their helpful comments on earlier versions of this paper. 


\section{Résumé}

Cette étude examine la pertinence des théories du capital humain, des signaux donnés au marché, et de l'identité sociale pour expliquer le rapport entre les études académiques formelles et le statut socio-économique d'un individu. Dans le cas des hommes comme des femmes, plus le niveau de scolarisation est élevé, plus on peut présumer que le statut socio-économique susceptible d'être atteint sera élevé. La théorie des signaux donnés au marché s'applique à la situation d'emploi des hommes puisqu'on observe une relation positive entre les connaissances acquises et le statut socio-économique atteint: les employeurs valorise donc le diplôme obtenu en autant qu'il dénote d'une formation de haut niveau adaptée au marché du travail. Cependant, selon cette étude, cette théorie ne décrit pas adéquatement la situation des femmes sur le marché du travail. Au surplus, certains économistes croient que la théorie du capital humain est inappropriée puisqu'elle suppose que les femmes choisissent volontairement de limiter la durée de leurs études et leur expérience professionnelle au bénéfice de leurs responsabilités familiales. Parallèlement, les approches analytiques examinant l'importance de l'identité sociale en tant que déterminant du statut socio-économique, en négligeant de tenir compte des aptitudes acquises à l'école, ignorent l'impact différentiel de l'éducation selon le sexe par rapport au pouvoir économique. De nouvelles théories doivent donc être développées pour poser le problème en fonction de ces limites, et pour corriger les inégalités afin d'atteindre l'équilibre entre les responsabilités professionnelles et familiales pour les hommes autant que pour les femmes.

Sirice World War II, educational spending has been a top priority for policy-makers in all Western industrialized countries, reflecting widely held beliefs that education enhances both national prosperity and individual success. At the individual level, studies of the impact of schooling on income and prestige levels have confirmed this view; however, most of these studies are grounded in theories of economic inequality developed during the 1960s when the labour force was dominated by men. With increases in women's levels of educational attainment and labour force participation, some economists, sociologists and higher education theorists have questioned the adequacy of these theories as explanations for women's labour market experience. It is not clear that women benefit from their education in the same way that men do. They are less likely to complete advanced degrees and they are concentrated in the humanities and the social sciences. When they leave the educational system and enter the labour force, they are frequently employed in low paid, low status 
jobs. Gender differences in educational attainment and occupational status may have implications for future research and the shaping of educational policy.

This study addresses these gender differences by re-examining the economic and sociological perspectives most commonly used to explain the effects of schooling on earnings and occupational prestige. 1 More importantly, it expands the focus of most existing studies by deriving separate analyses for women and men. It concludes with an interpretation of the findings in light of existing theories, suggesting new theoretical directions which will incorporate the work and family aspects of women's experience.

Both economists and sociologists have advanced theoretical explanations for the relationship between formal education and occupational success. Two economic perspectives and one sociological approach are reviewed in this paper. From neoclassical economics, human capital theory is based on the premise that the labour market is open and competitive. In this competitive climate, wages are determined by the amount of human capital that workers possess. Human capital consists of knowledge and skills acquired in school so, according to this argument, those who stay in school the longest build up supplies of human capital that will make them the most productive workers (Becker, 1964). Some economists contend that increasing years of employment experience also contribute to human capital reserves (Mincer, 1974). Those with the most years of education and experience receive the highest earnings and occupational prestige because they make the greatest contribution to productivity.

Although human capital theory focuses on the experience of men, it suggests that women's wages are relatively low because they leave the labour market to bear and raise children, forfeiting the opportunity to build up stores of human capital (Mincer \& Polachek, 1974). These views have recently been modified to reflect the growing participation of women in the labour force. Becker now argues that, in dual-earner families with children, husbands are more productive in the workplace than their wives because women expend more energy on household duties than on their paid work (1985). Thus, even though men and women may have similar stores of human capital and work the same number of hours in the labour force, women are less specialized and, as a result, earn less than their male counterparts. According to some economists, this version of human capital theory remains committed to the goal of workplace productivity, while ignoring the division of labour in the family and the possibility of discriminatory hiring and promotion practices as explanations for gender differences in earnings or prestige (Stevenson, 1988). Others criticize human 
capital theory on the grounds that it assumes individuals make voluntary choices about the level of their investment (Cohen, 1982; MacDonald, 1984).

A second economic perspective, the market signalling or filter theory of higher education, suggests that higher education acts as a screening device, selecting the most promising students and preparing them for the workplace (Arrow, 1973; Spence, 1973; Thurow, 1975). According to this view, years of completed education are important because they indicate that individuals have learned some job-related skills in school. However, educational credentials in the form of diplomas and degrees send a signal to employers that graduates have specialized knowledge and will readily absorb additional skills through occupational training. Employers can increase productivity by hiring people with credentials because they will not require a heavy investment in training costs.

Both human capital and market signalling theories link educational achievement to productivity: increased education means higher skill levels and these are reflected in higher earnings and occupational prestige for the most productive individuals. A competing argument, known as credentialism, is found in the sociological literature. The credentialist view sees education as a medium for shaping values and imparting the beliefs of a dominant group. Marxist interpretations of credentialism argue that the education system encourages people to be compliant, preparing them for jobs where obedience is valued (Bowles \& Gintis, 1976). The Weberian version of credentialism suggests that culture is symbolically created through day-to-day communications, so that successful students master the culture of the most influential status groups by acquiring the manners and habits necessary for occupational success (Collins, 1971, 1979; Parkin, 1979). Proponents of credentialism generally agree that skills learned in school are less important than group membership in determining earnings and prestige. A strict credentialist approach is apparent in Collins' argument that "schooling is very inefficient as a means of training for work skills" (1971, p. 1007). According to this view, years of schooling and diplomas or degrees lead to increased earnings and higher occupational prestige by effectively socializing students, not by imparting skills that are critical to job performance.

These three perspectives suggest three different predictions in regard to educational attainment and occupational prestige (Bidwell, 1989). According to human capital theory, education is valued because it provides skills and knowledge needed in the workplace. By implication, the theory predicts that each additional year of completed education is associated with an increase in socioeconomic status.? 
According to market signalling theory, education is useful in two ways. First, years of completed education send a social signal to employers, demonstrating that individuals have acquired some skills and knowledge in school. Second, educational credentials are more powerful than years of education as determinants of occupational success. They indicate that certificate-holders have crossed important transitional points in the educational system, gaining more specialized knowledge and skills with each degree earned. Both years of education and diplomas or degrees provide skills that lead to increased socioeconomic status but the most valued skills are associated with credentials. Thus, if occupational skill requirements are held constant, the effects of diplomas and degrees will disappear.

According to credentialism, each additional year of schooling represents commitment to the values, attitudes and beliefs of the dominant group, leading to jobs with high prestige. Diplomas and degrees strengthen this commitment, helping to ensure access to the best jobs. Education does not necessarily provide skills, so the effects of schooling, diplomas and degrees will remain strong, even when occupational skills are held constant.

The research literature bearing upon the relative merits of these three theories is inconclusive. American status attainment studies have repeatedly confirmed a positive relationship between educational attainment and occupational status when social origins are held constant (Blau \& Duncan, 1967; Featherman \& Hauser, 1978). ${ }^{3}$ Canadian researchers have reported that formal education affects the status of entry level jobs, and the link between education and occupational status has been strengthened over time (Boyd et al., 1985); however, status attainment studies deal only with levels of education, disregarding the contribution of credentials in explaining occupational status. As a result, they have been interpreted by invoking human capital theory or related approaches, but they have failed to indicate exactly how education and socioeconomic status are connected. Also, most have relied on occupational prestige scales designed to measure men's status, inviting criticism from feminist writers for their failure to explain underlying gender inequities (Acker, 1980). 4

Miller, Kohn, and Schooler (1986) have broadened the status attainment conceptualization of education as schooling. They report that, if school work is both substantively complex and performed without close supervision, students learn self-direction that will be useful in the workplace. Although they link education to occupational attainment, they confine their analysis to males and identify a self-directed approach that is characteristic of academic streams and upper-level white-collar jobs. ${ }^{5}$ 
Studies supporting the credentialist approach are rare, and findings are generally mixed (Jencks et al., 1972); however, Faia defends credentialism, asserting that educational certification is a "significant rite of passage" (1981, p. 1093). He distinguishes certification from years of schooling, reporting that high school diplomas, college degrees and graduate degrees are associated with heightened levels of occupational prestige. Years of college are also linked to occupational prestige but years of public/secondary schooling are not. Faia finds the strongest certification and schooling effects for respondents under forty but he does not pursue potential gender differences.

In summary, a substantial body of literature has been generated around the issue of education, earnings and occupational prestige but both theory and research generally reflect the experience of males. Human capital theory has assumed that women are less productive than men because they leave the labour force periodically to bear and raise children (Mincer \& Polachek, 1974). This has strengthened a view of women's work roles as secondary to their domestic duties, so most status attainment studies have focused exclusively on men (Featherman \& Hauser, 1978; Jencks et al., 1972; but see Treiman \& Terrell, 1975; Featherman \& Hauser, 1976; Sewell et al., 1980; Turrittin et al., 1983). Other studies have employed random sampling techniques but have either analyzed males and females together or eliminated women entirely (Faia, 1981; Miller et al., 1986).6

Comparative analyses of women and men are important because distinct gender differences are apparent in several key areas. Although overall levels of educational attainment are similar for women and men in Canada, women are less likely than men to complete advanced degrees. ' While women have made significant inroads in male-dominated areas of study, they are still found largely in the humanities and social sciences (Canada, 1990). Also, where men are evenly distributed across the occupational structure, women in the labour force are concentrated in a small number of relatively low-paying occupations, characterized by weak labour force attachment. These and other factors leave women in a disadvantaged position, relative to men.

\section{DATA AND METHODS}

This analysis is based on data from the Social Change in Canada survey, conducted by T. Atkinson, B. Blishen, M. Ornstein, and M. Stevenson at the Institute for Social Research at York University, Downsview, Ontario. This is a three-wave national study of adults, based on a multi-stage, stratified-cluster design, carried out in 1977, 1979 and 1981. The 1981 sample, consisting of 3,953 respondents, provides the basis for this study because it contains the 
necessary measures of education. Because the analysis is confined to respondents in the labour force, the number of valid cases is reduced to $2,431.8$

Six variables were used in the analysis: the dependent variable was socioeconomic status and the independent variables included two measures of education, number of years with present employer, number of hours worked per week and occupational skill requirements.

Socioeconomic status was represented by scores on two separate socioeconomic indexes-the Blishen-McRoberts index for men and the Blishen-Carroll index for women. The index for men's scores was based on Pineo-Porter (1967) prestige scores, income and education levels of occupations taken from 1971 Census data (Blishen \& McRoberts, 1976). Women's scores were generated in the same way, using the income and educational characteristics of female incumbents of occupations(Blishen \& Carroll, 1978). Although these socioeconomic indexes are widely used, their utility has been debated by many social scientists. Marxist and feminist writers have criticised them on theoretical grounds for their reliance on the status attainment tradition, arguing that they fail to identify structured inequalities between women and men (Burawoy, 1977; Acker, 1980; Horan, 1978; Stanworth, 1984).

The link between socioeconomic indexes and occupational prestige scores has also been cited as problematic. Prestige scores for men and women are almost identical, in spite of obvious structural inequities in the labour market (Boyd, 1986). This has led some critics to conclude that women's socioeconomic scores are inflated, and of limited use in comparative studies (England, 1979; Fox \& Suschnigg, 1989). Questions about the construct validity of the Pineo-Porter prestige scores have also been raised. These scores are based on the subjective ranking of occupations but results can differ according to the education, occupation, income, race, ethnicity or gender of those doing the ranking (Guppy \& Goyder, 1984). Others have found that the sex composition of an occupation can affect prestige rankings (Guppy \& Siltanen, 1977). Although the efficacy of socioeconomic indexes is dependent on the analytical value of prestige scores, Blishen et al. argue that they have minimized the contribution of prestige scores in the construction of their indexes (1987).${ }^{9}$ Finally, some social scientists have identified methodological problems with separate socioeconomic indexes for men and women, especially in male- or female-dominated occupations. 10

In spite of these criticisms, separate male and female indexes are used in this study because, in my opinion, they are the most effective measures of socioeconomic status available. It is true that women's scores are almost the 
same as men's scores. This pattern does not reflect the male-female earnings differential. It is probably related to occupational sex segregation: women are concentrated in a limited number of female-dominated, typically white-collar occupations. In spite of their low pay, these jobs carry higher occupational prestige than most blue-collar jobs. In contrast, men's jobs range across the entire occupational spectrum, with relatively small numbers of incumbents in managerial and professional positions and a greater concentration in blue-collar jobs. Since the purpose of this study is to examine gender differences in the relationship between education and socioeconomic status, the Blishen scores used to measure socioeconomic status do not detract from this purpose.

The first measure of education was based on the number of years completed and the second indicated the highest level of certification achieved. Respondents were asked "How many years of schooling have you completed altogether?" and "What is the highest level of education that you have completed?". Certification or highest level of education was recoded as five dichotomous variables--no diploma or degree, high school diploma, Bachelor's degree, Master's degree and Professional degree or Ph.D., with $1=$ present and $0=$ absent. Number of years with present employer was used as a measure of work experience and number of hours worked per week was used to measure labour supply.

Information on job skill requirements was provided by a scale of cognitive complexity developed from the Canadian Classification and Dictionary of Occupations 1971 worker-trait data (Hunter \& Manley, 1986; Hunter, 1988). The scale is a composite drawn from forty-three different aspects of the task requirements of approximately 6,500 different occupations, collapsed to match the 486 occupational categories of the 1971 Census. The scale of cognitive complexity includes such variables as scientific and technical work, intelligence, abstract and creative work, general educational development, and numerical, verbal, or spatial perceptions of work, referring generally to the application of knowledge or analytical thought to occupational tasks."

\section{ANALYSIS}

Table 1 shows the means and standard deviations for the study variables, for men and women separately. In line with previous findings, men and women have similar Blishen scores.12 Blishen scores do not reflect gender inequities in earnings, but our primary concern here is with the impact of the independent variables on these scores. Mean levels of schooling are similar, but men are more likely than women to acquire advanced degrees. Gender differences are more pronounced for number of years with present employer and number of 
Table 1

Means and Standard Deviations Study Variables,

Men $(\mathrm{N}=1,269)$ and Women $(\mathrm{N}=1,162)^{\mathrm{a}}$

\begin{tabular}{lrrrr} 
& \multicolumn{2}{c}{ Men } & \multicolumn{2}{c}{ Women } \\
\cline { 2 - 5 } Variable & $\mathrm{X}$ & \multicolumn{1}{c}{$\mathrm{s}$} & $\mathrm{X}$ & \multicolumn{1}{c}{$\mathrm{s}$} \\
\hline Years of schooling & 12.71 & 3.94 & 12.87 & 3.23 \\
High school b & .44 & .50 & .58 & .49 \\
Bachelor's c & .13 & .33 & .11 & .31 \\
Master's d & .04 & .19 & .02 & .15 \\
Ph.D., professional $\mathrm{e}$ & .03 & .16 & .01 & .08 \\
Years employer & 8.67 & 9.40 & 5.64 & 6.27 \\
Hours per week & 42.66 & 11.45 & 34.19 & 12.04 \\
Blishen score & 46.06 & 15.79 & 46.69 & 14.53 \\
Cognitive complexity & .29 & 1.01 & .21 & .81 \\
\hline
\end{tabular}

a Numbers of cases vary slightly because of missing values

$\mathrm{b}$ High school $=1$, other $=0$

c Bachelor's degree $=1$, other $=0$

'Master's degree $=1$, other $=0$

e $\mathrm{Ph}$. D. or professional degree $=1$, other $=0$

hours worked per week: on average, men have three more years with their present employer and work eight and a half hours more per week than women.

Table 2 shows the results of the regression of socioeconomic status on years of schooling and four dichotomous variables for educational certificates. For both men and women, a significant increase in socioeconomic status is evident for each additional year of schooling attained and for each of the certification variables. When years of education squared was added to the equations, no significant increment to $R$ ? was evident. This suggests that the relationship between years of schooling and socioeconomic status is linear. The effect of formal education on socioeconomic status appears to include both schooling and certification. However, we cannot establish theoretical links at this point because both of these educational effects are supported by human capital theory, market signalling theory and credentialism. 
Table 2

Unstandardized Regressions of Socioeconomic Status on Years of Schooling and Certificates, Men $(\mathrm{N}=1,253)$ and Women $(\mathrm{N}=1,154)$

\begin{tabular}{lcc}
\hline & \multicolumn{2}{c}{ Regression Coefficient } \\
Independent Variable & Men & Women \\
\hline Years of schooling & $1.49^{* * *}$ & $2.01^{* * *}$ \\
High school a & $2.01^{*}$ & $4.24^{* * *}$ \\
Bachelor's a & $10.61^{* * *}$ & $10.07^{* * *}$ \\
Master's a & $10.10^{* * *}$ & $15.48^{* * *}$ \\
Ph.D., Professional a & $12.49^{* * *}$ & $11.84^{* * *}$ \\
Constant & $24.25^{* *}$ & $16.76^{* * *}$ \\
Adjusted Rs & $.34^{* * *}$ & $.42^{* * *}$ \\
\hline
\end{tabular}

a All dummies scored $0,1.1=$ present. Omitted category is less than high school graduation

${ }^{*}=\mathrm{p}<.05,{ }^{* *}=\mathrm{p}<.01,{ }^{* *}=\mathrm{p}<.001$

Table 3

Unstandardized Regressions of Cognitive Complexity on Years of Schooling and Certificates. Men $(\mathrm{N}=1,253)$ and Women $(\mathrm{N}=1,154)$

\begin{tabular}{lcc}
\hline & \multicolumn{2}{c}{ Regression Coefficient } \\
Independent Variable & Men & Women \\
\hline Years of schooling & $.075^{* * *}$ & $.116^{* * *}$ \\
High school a & $.160^{*}$ & $.124^{*}$ \\
Bachelor's a & $.729^{* * *}$ & $.298^{* *}$ \\
Master's a & $.859^{* *}$ & $.555^{* * *}$ \\
Ph.D., Professional a & $1.234^{* *}$ & $.728^{* *}$ \\
Constant & $-.896^{* *}$ & $-1.405^{* * *}$ \\
Adjusted Rs & $.311^{* * *}$ & $.333^{* * *}$ \\
\hline
\end{tabular}

a All dummies scored $0,1.1$ = present. Omitted category is less than high school graduation

${ }^{*}=p<.05,{ }^{* *}=p<.01,{ }^{* * *}=p<.001$ 
Table 4

Unstandardized Regressions of Socioeconomic Status on Cognitive Complexity. Men $(\mathrm{N}=1,257)$ and Women $(\mathrm{N}=1.156)$

Regression Coefficient

Independent Variable Men

Women

Cognitive complexity

$13.17^{* * *}$

$14.72^{* * *}$

Constant

$42.29^{* * *}$

$43.64^{* * *}$

Adjusted Rs

$.71^{* * *}$

$.68^{* * *}$

${ }^{*}=\mathrm{p}<.05,{ }^{* *}=\mathrm{p}<.01,{ }^{* * *}=\mathrm{p}<.001$

According to market signalling theory, both years of schooling and certificates lead to high-skill jobs. These jobs, in turn, carry high socioeconomic status. Conversely, credentialism in its strictest form holds that years of schooling and certificates are not related to high-skill jobs, and skill is not associated with high socioeconomic status. In Table 3 , cognitive complexity is regressed on years of schooling and certificates. Jobs that are high in cognitive complexity are linked to additional years of schooling and certificates for both men and women. Table 4 presents the regression of socioeconomic status on cognitive complexity, indicating that high-skill jobs are also associated with heightened socioeconomic status. These findings are not consistent with the strict interpretation of credentialism.

If more education leads to higher skill jobs and heightened socioeconomic status, then how can this be explained on theoretical grounds? If the market signalling approach holds, then occupational skill requirements should explain most of the relationship between certificates and socioeconomic status. If credentialism prevails, then certificates should be more important than skills in predicting socioeconomic status. This argument is tested by regressing socioeconomic status on years of schooling, certificates and cognitive complexity. The results, shown in Table 5, reveal pronounced gender differences. For men, none of the certification variables is significant. The market signalling approach is supported because diplomas and degrees appear to be valued by employers if they provide a supply of employees with high skill levels. For women, all levels of certification, except $\mathrm{Ph} . \mathrm{D}$. or professional degrees remain significant when occupational skills are held constant. Market signalling theory is not relevant because credentials appear to be valued for themselves, not because they guarantee useful skills. 
Table 5

Unstandardized Regressions of Socioeconomic Status on Years of Schooling. Certificates, and Cognitive Complexity, Men $(\mathrm{N}=1,253)$ and Women $(\mathrm{N}=1,154)$

\section{Regression Coefficient}

Independent Variable

Men

Women

Years of schooling

High school a

Bachelor's a

Master's a

Ph.D., Professional a

Cogntive complexity

Constant

Adjusted Rs

$.60^{* * *}$

.12

1.99

$-.05$

$-2.10$

$11.82^{* * *}$

$34.84^{* * *}$

$.73^{* * *}$
$.62^{* * *}$

$2.74^{* * *}$

$6.48^{* * *}$

$8.79^{* * *}$

3.07

$12.04^{* * *}$

$33.68^{* * *}$

$.73^{* * *}$

a All dummies scored $0,1.1$ = present. Omitted category is less than high school graduation

" $=\mathrm{p}<.05,{ }^{* *}=\mathrm{p}<.01,{ }^{* * *}=\mathrm{p}<.001$

Table 6 shows results for the fully specified equations in which socioeconomic status is regressed on years of schooling, certificates, years with present employer, hours worked per week and cognitive complexity. Once again, certificates have no significant effect on socioeconomic status for men, whereas all levels of certification except Ph.D. or professional degrees remain strong for women. Years of schooling and cognitive complexity are statistically significant for both sexes, while hours worked per week is significant for men only and years with employer is significant for women only. The market signalling explanation is still appropriate for men, but not for women.

\section{DISCUSSION}

These findings fail to support human capital theory (Becker, 1964, 1985) as an explanation for the relationship between formal education and socioeconomic status. It is true that years of schooling are associated with heightened socioeconomic status for both sexes when the remaining variables are held constant; however, women do not benefit from educational certification in the way that men do. 
Table 6

Unstandardized Regressions of Socioeconomic Status on Years of Schooling, Certificates, Years with Present Employer, Hours Worked per Week, and Cognitive Complexity, Men $(\mathrm{N}=1,242)$ and Women $(\mathrm{N}=1,144)$

\section{Regression Coefficient}

Independent Variable

Men

Women

Years of schooling

$.57^{* * *}$

.03

High school a

1.72

Bachelor's a

Master's a

Ph.D., Professional a

Years with employer

Hours per week

Cognitive complexity

Constant

Adjusted Rs
$-.30$

$-2.13$

$-.01$

$-.16^{* * *}$

$12.08^{* * *}$

$42.17^{* * *}$

$.75^{* * *}$
$.68^{* * *}$

$2.61^{* * *}$

$6.34^{* * *}$

$8.68^{* * *}$

3.22

$.15^{* * *}$

$-.03$

$11.83^{* * *}$

$33.40^{* * *}$

$.73^{* * *}$

a All dummies scored $0,1.1$ = present. Omitted category is less than high school graduation

$*=p<.05,{ }^{* *}=p<.01,{ }^{* * *}=p<.001$

The results indicate that the market signalling view is relevant for men in this study (Arrow, 1973; Spence, 1973; Thurow, 1975). Their skills are valued by employers and their certificates are accepted as evidence that they bring useful skills to the labour market. Women do not share this experience: certificates are important but skills are not valued in the way that they are for men.

Finally, the strict credentialist argument (Bowles \& Gintis, 1976; Collins, 1971, 1979; Parkin, 1979) fails to explain the links between education and socioeconomic status for either men or women because it assumes that education does not provide marketable skills. In this study, years of schooling and diplomas or degrees lead to high-skill jobs for both sexes.

How then can the experience of women be explained in theoretical terms? Existing theories are not adequate to address gender differences in educational attainment and occupational success. Human capital theory focuses on productivity and the maximization of profits, without explaining why women, rather than men, leave the labour force or devote more energy to household 
duties than paid work. Economists who challenge the neoclassical view argue that it assumes men and women have equal opportunities to achieve in school and in the workplace but women make voluntary choices to limit their human capital by choosing specific educational programs, learning "women's" skills and moving into female-dominated areas of work (Cohen, 1982; MacDonald, 1984). MacDonald suggests that neoclassical economic theories can be reshaped to accommodate women's experience by recognizing their work within the home as unpaid labour.

The strict credentialist view is also limited where women are concerned because it does not address the issue of education and skills. Skills are important, especially when considered in light of gender differences. Women and men acquire different kinds of skills in the educational system, they are placed in segregated occupations on the basis of their skills, and differential skills reinforce power differences in the workplace. Much more work is needed to gain an understanding of skills in the context of power relationships (Gaskell, 1986; Smith, 1990).

Although critics of existing economic and sociological theories offer hope for an expanded vision, current theoretical perspectives fail to explain the findings for this study. It has been demonstrated here that education and skills operate differently for men and women; however, it is not sufficient to report gender differences in training and the amount of work experience gained. A broader theoretical view would incorporate the other half of women's lives-the domain of the family. Sound educational policies reflecting gender differences in education and work experience depend on research which examines women's expectations in regard to their educational attainment, their work patterns and their family time. This could be considered in light of employers' perceptions and overriding societal beliefs about the work and family commitments of women and men.

\section{Notes}

1 Measures of socioeconomic status have varied over time. The terms "occupational prestige" and "occupational status" are used here in reference to previous research.

2 Socioeconomic status in this context consists of earnings and occupational prestige. The empirical definition of sociocconomic status is presented in the methods section.

3 In status attainment studies, occupational status incorporates measures of income and occupational prestige. See Bielby (1981) for a summary of this literature. 
4 See Boyd (1986) for a discussion of the inclusion of women in status attainment models.

5 MacKinnon and Anisef (1979) extend earlier status attainment work by adding self-assessment as a predictor of aspiration/attainment but their sample is confined to Grade 12 males in Ontario.

6 See Eichler (1988) for a discussion of gender insensitivity in her discussion of sex-related bias in research.

7 In 1987, women earned $53 \%$ of the bachelor's degrees, $45 \%$ of the master's degrees and 29\% of the Ph.D. degrees (Canada, 1990, p. 47).

8 The questionnaire design eliminates students, those doing housework and those who are retired, unemployed, disabled or on strike. The sample includes both full-time and part-time workers, although it is not possible to separate these two groups. If the Statistics Canada designation of part-time work as "less than thirty hours per week" (Wallace, 1983, p. 39) is used, then $14 \%$ of the respondents are part-time workers.

9 See Blishen et al. for a detailed discussion of the composition of the socioeconomic scales (1987, pp. 469-470).

10 As an alternative to separate male and female indexes, Boyd has developed a "total" index based on the income and educational characteristics of men and women for occupations listed in the 1971 Census (1986). In a comparison with the Blishen-McRoberts and Blishen-Carroll indexes, she reports that the level of male-female disparity is slightly higher in her index, making it a more realistic measure of sex differences in socioeconomic status.

11 The scale of cognitive complexity is one of eight different measures of the skill and task requirements of occupations, designed to reflect a range of theoretical variables. A detailed discussion of the theoretical literature and the factor analyses used to derive these scales is presented by Hunter and Manley (1986) and Hunter (1988).

12 Blishen et al. report median 1981 sociocconomic scores of 39.19 and 38.15 for men and women, respectively (1987, p. 472).

\section{References}

Acker, J. (1980). Women and stratification: A review of recent literature. Contemporary Society, 9, 25-35.

Armstrong, P., \& Armstrong, H. (1984). The double ghetto: Canadian women and their segregated work (2nd ed.). Toronto: McClclland and Stewart.

Armstrong, P., \& Armstrong, H. (1990). Theorizing women's work. Toronto: Garamond Press.

Arrow, K. (1973). Higher education as a filter. Journal of Public Economics, 2, 193-216.

Atkinson, T., Blishen, B., Ornstein, M., \& Stevenson, M. (1977-1981). Quality of life:

Social change in Canada [Machinc-readable data file]. Downsvicw: Institute for Social Research, York University.

Becker, G. (1964). Human capital: A theoretical and empirical analysis, with special reference to education. New York: Columbia University Press. 
Becker, G. (1985). Human capital, effort, and the sexual division of labor. Journal of Labor Economics 3: S33-S58.

Bell, D. (1973). The coming of post-industrial society. New York: Basic.

Berg, I. (1970). Education and jobs: The great training robbery. New York: Praeger.

Bidwell, C. (1989). The meaning of educational attainment. In A. C. Kerckhoff (Ed.), Research in the sociology of education and socialization (Vol. 8, pp. 117-138). Greenwich: JAI Press.

Bielby, W. (1981). Models of status attainment. In D. Trciman \& R. Robertson (Eds.), Research in social stratification and mobility (Vol. 1, pp. 3-26). Greenwich: JAI Press.

Blau, P. M., \& Duncan, O. D. (1967). The American occupational structure. New York: Wiley.

Blishen, B., \& Carroll, W. (1978). Sex differences in a sociocenomic index for occupations in Canada. The Canadian Review of Sociology and Anthropology, 4, $41-52$.

Blishen, B., Carroll, W., \& Moore, C. (1987). The 1981 sociocconomic index for occupations in Canada. The Canadian Review of Sociology and Anthropology, 24, $465-488$.

Blishen, B., \& McRoberts, H. (1976). A revised sociocconomic index for occupations in Canada. The Canadian Review of Sociology and Anthropology, 13, 71-79.

Bohrnstedt, G., \& Knoke, D. (1988). Statistics for social data analysis. Itasca, IL: F. E. Peacock

Bowles, S., \& Gintis, H. (1976). Schooling in capitalist America. New York: Basic.

Boyd, M. (1986). Sociocconomic indices and sexual inequality: A tale of scales. The Canadian Review of Sociology and Anthropology, 23, 457-480.

Boyd, M., Goyder, J., Jones, F., McRoberts, H., Pineo, P., \& Porter, J. (1985). Ascription and achievement: Studies in mobility in Canada. Ouawa: Carleton University Press.

Burawoy, M. (1977). Social structure, homogenization, and the process of status attainment in the United States and Great Britain'. American Journal of Sociology, 82, 1031-1042.

Canada. (1983). Education in Canada. Ottawa: Statistics Canada.

Canada. (1990). Women in Canada. Ottawa: Statistics Canada.

Cohen, M. (1982). The problem of studying 'economic man'. In A. Miles \& G. Finn (Eds.), Feminism in Canada (pp. 89-101). Montreal: Black Rose.

Collins, R. (1971). Functional and conllict theories of educational stratification. American Sociological Review, 36, 1002-1019.

Collins, R. (1979). The credential society. New York: Academic Press.

Davis, K., \& Moore, W. (1945). Some principles of stratification. American Sociological Review, 36, 1002-1019.

Eichler, M. (1988). Nonsexist research methods. Boston: Unwin Hyman.

England, P. (1979). Women and occupational prestige: A case of vacuous sex equality. Signs, 5, 252-265.

Faia, M. (1981). Selection by certification: A neglected variable in stratification research. American Journal of Sociology, 86, 1093-1111. 
Featherman, D., \& Hauser, R. (1976). Sexual incqualities and socioeconomic achievement in the United States, 1962-73. American Sociological Review, 41, $462-483$.

Featherman, D., \& Hauser, R. (1978). Opportunity and change. New York: Academic Press.

Fox, J., \& Suschnigg, C. (1989). Gender and the prestige of occupations. The Canadian Journal of Sociology, 14, 353-360.

Gaskell, J. (1986). Conceptions of skill and the work of women: Some historical and political issues. In R. Hamilton \& M. Barretl (Eds.), The politics of diversity (pp. 361-380). Montreal: Book Centre.

Guppy, N., \& Goyder, J. (1984). Consensus on occupational prestige: A reassessment of the evidence. Social Forces, 62, 709-725.

Guppy, N., \& Siltanen, J. (1977). A comparison of the allocation of male and female occupational prestige. The Canadian Review of Sociology and Anthropology, 14, $320-330$.

Horan, P. (1978). Is status attainment research atheoretical? American Sociological Review, 43, 534-541.

Hunter, A. (1986). Class Tells (2nd ed.). Toronto: Butterworths.

Hunter, A. (1988). Formal education and initial employment. American Sociological Review, 53, 753-765.

Hunter, A., \& Manley, M. (1986). On the task content of work. The Canadian Review of Sociology and Anthropology, 23, 47-71.

Jencks, C. (1979). Who gets ahead? New York: Basic.

Jencks, C., Smith, M., Acland, H., Bane, M. J., Cohen, D., Gintis, H., Heyns, B., \& Michelson, S. (1972). Inequality. New York: Basic.

MacDonald, M. (1984). Economics and feminism: The dismal science. Studies in Political Economy, 15, 151-178.

MacKinnon, N., \& Anisef, P. (1979). Self-assessment in the carly educational attainment process. The Canadian Review of Sociology and Anthropology, 16, 305-319.

Miller, K., Kohn, M., \& Schooler, C. (1986). Educational self-direction and personality. American Sociological Review, 51, 372-390.

Mincer, J. (1974). Schooling, experience, and earnings. New York: National Bureau of Economic Rescarch.

Mincer, J., \& Polachek, S. (1974). Family investments in human capital: Earnings of women. Journal of Political Economy, 82, 76-111.

Parkin, F. (1979). Marxism and class theory: A bourgeois critique. London: Tavistock.

Pinco, P., \& Porter, J. (1967). Occupational prestige in Canada. The Canadian Review of Sociology and Anthropology, 4, 24-40.

Porter, J. (1985). Canada: The societal context of occupational allocation. In M. Boyd, J. Goyder, F. Jones, H. McRoberts, P. Pineo, \& J. Porter (Eds.), Ascription and achievement: Studies in mobility in Canada (pp. 29-65). Ottawa: Carleton University Press.

Sewell, W., Hauser, R., \& Featherman, D. (1976). Schooling and achievement in American society. New York: Academic Press. 
Sewell, W., Hauser, R., \& Wolf, W. (1980). Sex, schooling and occupational status. American Journal of Sociology, 86, 551-583.

Smith, M. (1990). What is new in "new structuralist" analyses of earnings? American Sociological Review, 55, 827-841.

Spence, M. (1973). Job market signalling. Quarterly Journal of Economics, 87, 355-374.

Stanworth, M. (1984). Women and class analysis: A reply to John Goldthorpe. Sociology, 18, 159-170.

Stevenson, M. (1988). Some economic approaches to the persistence of wage differences between men and women. In A. Stromberg \& S. Harkess (Eds.), Women Working (3rd ed., pp. 87-100). Mountain View, CA: Mayficld.

Stockard, J. (1985). Education and gender equality: A critical review. In A. C. Kerckhoff (Ed.), Research in the sociology of education and socialization (Vol. 5, pp. 299-326). Greenwich: JAI Press.

Thurow, L. (1975). Generating inequality: Mechanisms of distribution in the U.S. economy. New York: Basic.

Treiman, D., \& Terrell, K. (1975). Sex and the process of status attainment: A comparison of working women and men. American Sociological Review, 40, 174-200.

Turrittin, A., Anisef, P., \& MacKinnon, N. (1983). Gender differences in educational achievement: A study of social inequality. The Canadian Journal of Sociology, 8 , 395-419.

Wallace, J. (1983). Part-time work in Canada. Ottawa: Labour Canada. 